Журнал «Герспективитаінноваціїнауки»

(Серія «Педагогіка», Серія «Гиихологія», Серія«Медицина»

№5(5) 2021

УДК 37.0

https://doi.org/10.52058/2786-4952 -2021-5(5)-310-322

Жукова Анна Робертівна аспірантка педагогічного факультету, Львівський національний університет імені Івана Франка, заступник директора 3 виховної роботи, Львівський коледж транспортної інфраструктури, вул. Снопківська, 47, м. Львів, 79000, e-mail: annetta000@gmail.com, https://orcid.org/0000-0002-7292-1605

\title{
ТЕОРЕТИКО-МЕТОДОЛОГІЧНІ АСПЕКТИ ФОРМУВАННЯ ЛІДЕРСЬКОЇ КОМПЕТЕНЦІЇ У СТУДЕНТІВ
}

Анотація. Стаття присвячена теоретико-методологічним аспектам формування лідерської компетенції у студентів як однієї з основних у процесі становлення молодих спеціалістів. У роботі з'ясовано теоретичні підходи різних дослідників до визначення понять «лідер», «лідерство» та «лідерська компетенція». Охарактеризовано головні принципи формування лідерської компетенції та визначено, що процес формування лідерської компетенції у студентів має відбуватися протягом всього періоду навчання та бути системним i цілеспрямованим. Виокремлено складові, які забезпечують ефективний процес розвитку лідерської компетенції, зокрема мотиваційні, емоційно-вольові та ділові. Окрім того, розглянуто головні напрями роботи та види діяльності, такі як навчальна діяльність, конкурсна, дослідницька, проєктна, громадська й представницька, що $є$ важливими у процесі формування лідерської компетенції у студентів. Виділено та охарактеризовано головні етапи та педагогічні умови, які сприяють розвитку лідерської компетенції. У підсумку зазначається, що лідерська компетенція $є$ одним із важливих аспектів становлення майбутнього спеціаліста, його успішної професійної реалізації та діяльності. Її формуванню слід приділяти особливу увагу, а тому необхідно забезпечити створення ситуацій, які надаватимуть студентам можливості для реалізації їх лідерських задатків, здібностей та реалізації їх лідерського потенціалу. Варто зосередитися не лише на формуванні лідерської компетенції під час навчальної діяльності, а й під час наукової роботи та позанавчальної діяльності. Адже лише створюючи відповідні педагогічні умови, застосовуючи необхідні види діяльності, враховуючи особливості студентів та забезпечуючи безперервність процесу формування лідерської компетенції, можна досягти успіху та виховати справжніх фахівців-лідерів.

Ключові слова: лідерство, лідерська компетенція, лідер, лідерські якості студентів, формування лідерських якостей. 
Zhukova Anna Robertivna Postgraduate student of the Faculty of Pedagogy, Ivan Franko National University of Lviv, Deputy Director for Educational Work, Lviv College of Transport Infrastructure, Snopkivska St., 47, Lviv, 79000, e-mail: annetta000@gmail.com, https://orcid.org/0000-0002-7292-1605

\section{THEORETICAL AND METHODOLOGICAL ASPECTS OF LEADERSHIP COMPETENCE FORMATION IN STUDENTS}

Abstract. The article is devoted to the theoretical and methodological aspects of the formation of students' leadership competence as one of the main in the process of becoming young professionals. The paper clarifies the theoretical approaches of different researchers to the definition of "leader", "leadership" and "leadership competence". The main principles of the formation of leadership competence are described and it is determined that the process of the formation of students' leadership competence should take place during the whole period of study and be systematic and purposeful. The components that ensure an effective process of development of leadership competence, including motivational, emotional and business, are identified. In addition, the main areas of work and activities are considered, such as educational, competition, research, project, public and representative activities, which are important in the process of forming students' leadership competence. The main stages and pedagogical conditions that contribute to the development of leadership competence are highlighted and characterized. In conclusion, it is noted that leadership competence is one of the important aspects of becoming a future specialist, his successful career and activity. Particular attention should be paid to its formation, and therefore it is necessary to ensure the creation of situations that will provide students with opportunities to realize their leadership skills, abilities and realize their leadership potential. It is worth focusing not only on the formation of leadership competence during educational activities, but also during research and extracurricular activities. After all, only by creating appropriate pedagogical conditions, applying the necessary activities, taking into account the characteristics of students and ensuring the continuity of the process of leadership competence formation, it is possible to achieve success and educate true leaders.

Keywords: leadership, leadership competence, leader, leadership qualities of students, formation of leadership qualities.

Постановка проблеми. Відповідно до сучасних умов оновлення та розбудови всіх сфер суспільного життя, нової парадигми освіти та високих вимог до підготовки молодих спеціалістів постає проблема організації навчального процесу таким чином, щоб випускники навчальних закладів володіли не лише необхідним багажем професійних знань, умінь та навичок, а й певними лідерськими якостями, які б дали їм змогу успішно реалізувати свій творчий потенціал на практиці та досягти неабияких успіхів. Адже, сучасне суспільство потребує лідерів, які володіють яскраво вираженими 
організаторськими компетенціями й внутрішнім прагненням до соціальної активності, які спроможні об’єднати навколо себе людей для досягнення поставлених цілей, готові до тривалої та напруженої роботи заради створення сприятливих умов для подальшого розвитку.

Мета статті полягає у розгляді та узагальнені основних підходів до понять «лідерство» та «лідерська компетенція», а також аналізі основних принципів формування лідерської компетенції у студентів.

Аналіз останніх досліджень і публікацій. Проблеми лідерства, лідера та лідерської компетенції цікавлять дослідників вже досить тривалий час. Зокрема, цим проблемам присвячують свої праці такі вітчизняні науковці як С.В. Шекшня, О.Г. Романовський, Т.В. Волосюк, Т.В. Савицька, А.В. Чорний, К.А. Мухіна, І.Є. Штученко, Я.А. Денисенко, Е. Б. Моргунов, С.А. Ковальчук, О.В. Хмизова та ін., а також закордонні науковці серед яких М. К. Вебер, У. Г. Бенніс, Ф. Фідлер, Дж. Хемфілл та ін. Проте, попри досить велику кількість публікацій, що присвячені проблемі лідерства та формуванню лідерських якостей і лідерської компетенції, не можна вважати іiі повністю розкритою та завершеною, адже теоретико-методологічні аспекти формування лідерської компетенції у студентів $\epsilon$ не до кінця вивченими та проаналізованими, що й зумовило вибір нами даної теми дослідження.

Виклад основного матеріалу. Як показало вивчення наукової літератури, що присвячена проблемам лідерства та формування лідерської компетенції, ці питання набули статусу науково-практичної проблеми ще на початку XX століття і залишаються актуальними на сучасному етапі. Сьогодні існує безліч підходів до трактування та визначення понять «лідер», «лідерство» та «лідерська компетенція», тому спочатку зупинимося на розгляді цих понять та різних підходів до їх трактування.

На думку Ф. Фідлера та Дж. Хемфілла, лідер є авторитетним членом групи або організації, який здатний генерувати ідеї та здійснювати вплив на оточуючих з метою об'єднання зусиль для досягнення поставленої мети [10].

Б.Д. Паригін вважав, що лідером є член певної групи, який спонтанно виконує роль неофіційного керівника в умовах специфічної та досить значущої ситуації, з метою забезпечення організації спільної колективної діяльності людей для найшвидшого та найуспішнішого досягнення загальної мети. Таке визначення лідера не втрачає актуальності й на сьогоднішній момент [7].

С.А. Гармаш стверджує, що лідером $є$ особистість, яка володіє розвинутими комунікативними вміннями, здатна словами впливати на інших людей та з якою виявляє бажання співпрацювати більшість колективу [4, с. 37].

На переконання Т.Є. Вежевич, лідером є особистість, якій всі інші члени групи надають право брати на себе найвідповідальніші рішення, а також визначати характер і напрям діяльності всієї групи. При цьому ефективна діяльність групи напряму залежить від взаємин офіційного та неофіційного лідера чи лідерів. А володіючи знаннями про реальні міжособистісні взаємостосунки у групі, викладач має можливість спрямувати їх у потрібне 
річище, адже лідер покликаний допомагати у навчальному та виховному процесах [1, с. 25].

Крім того, вважається, що лідер визначається групою з огляду на яскраво виражені особистісні якості, що $є$ зразковими для ії членів та імпонують їм. Найважливішими такими якостями є: ширша поінформованість щодо питання, яке треба вирішити; зацікавленість у досягненні групової мети; ініціативність і висока соціальна активність; енергійність; емоційна стійкість; організаторські здібності; упевненість у собі; доброзичливість і емпатія; розумові здібності тощо [10].

Науковці С.В. Шекшня, О. Г. Романовський, М. К. Вебер та У. Г. Бенніс розглядають лідерство як активний процес, що полягає у створенні та підтримці рольової структури в груповій взаємодії.

Т.В. Волосюк вважає, що лідерство - це реалізація організаційного керівництва, що є об'єднаним втіленням реальних подій та особистих якостей. Це здатність здійснювати вплив на групи та на окремих осіб, скеровуючи їх зусилля у напрямі досягнення певних цілей, тобто забезпечувати ефективну взаємодію членів групи [3, с. 126].

Відповідно до визначення Л.М. Сергєєвої, лідерство полягає в умінні пробудити в людях мрію, до якої вони будуть крок за кроком наближатися. Це можливість впливу на людей та спрямування їх діяльності на досягнення цілей певної організації, підприємства чи команди [9, с. 12].

Ряд дослідників вважає, що лідерство являється процесом внутрішньої соціальної організації та управління спілкуванням, а також діяльністю членів малої групи, яка здійснюється у спонтанно створених малих групах. Вони стверджують, що у кожній малій групі $\epsilon$ свій лідер, а в залежності від спрямування діяльності мікрогрупи, лідерів може бути й кілька.

Щодо поняття «лідерська компетенція», то всебічний аналіз наукової літератури дозволяє прийти до висновку, що лідерська компетенція виражається у здатності студентів помічати найменші ознаки змін та передбачати тенденції, які тільки виникають, швидко реагувати на зміни та проявляти гнучкість з метою пристосування до нових вимог середовища, узгоджувати власні потреби й цінності з потребами та цінностями інших людей 3 метою злагодженої й ефективної діяльності та формування команди, а також створювати всі необхідні умови для досягнення мети та чітко й наполегливо рухатися до їі досягнення.

На думку О.В. Хмизової, структура лідерської компетенції має три головні компоненти, а саме:

1) когнітивний, що включає переконання, вміння та навички;

2) мотиваційно-емоційний, до складу якого входять потреби, мотиви, цінності, емоції та ставлення;

3) діяльнісно-поведінковий, до якого відносяться вчинки, поведінка, дії й практична реалізація [11, с. 316].

Таким чином, проаналізувавши сучасні підходи до трактування понять «лідер», «лідерство» та «лідерська компетенція», ми можемо зробити висновок, 
що лідером є командний гравець, який володіє широким комплексом знань, умінь, навичок та характеристик, в основі яких лежить здатність до колективної взаємодії. Лідерство - це унікальна здатність особистості здійснювати вплив на інших людей та спрямовувати їх діяльність на досягнення конкретних цілей. А лідерська компетенція - це набір знань, вмінь та навичок, які дозволяють особистості прогнозувати, швидко пристосовуватися та реагувати на певні ситуації, вести за собою людей та досягати поставленої мети.

Щодо питання формування лідерських компетенцій у студентів, насамперед зазначимо, що цей процес має здійснюватися протягом усього навчання у рамках, як аудиторних, так і позааудиторних занять та має бути системним і цілеспрямованим. Варто зазначити, що нагальну необхідність формування лідерської компетенції у студентів зумовило входження України до Свропейської освітньої системи. Адже, основна увага в компонентах Болонського процесу приділяється ряду особистісних чинників, серед яких піднесення ролі студентського самоврядування, забезпечення участі студентства в акредитації навчального закладу, а також необхідність та важливість самоактивності в опануванні певної професії. Проте, на наше переконання, не можна обмежуватися тільки запропонованим, необхідно приділити значну увагу також піднесенню гуманістичної культури особистості, плеканню національного менталітету, а також активному впровадженню світоглядних і виховних предметів.

Дослідники Е. Б. Моргунов, С.А. Ковальчук та С. В. Шекшня стверджують, що однією із перших умов формування лідерських якостей $є$ надання можливості бути лідером, а до факторів, що можуть впливати на процес формування та розвиток лідерських здібностей вони відносять специфіку діяльності, в яку включена людина, особливості сімейного виховання й дозвілля, а також специфіку середовища іiі спілкування тощо. Окрім того, вони зазначають, що важливим для формування лідерських якостей студентів $є$ навчання лідерству, до складу якого входять різноманітні знання з психології особистості, психології лідерства, соціальної психології та професійні й комунікативні компетенції [2].

На думку О. Євтіхова, лідерські компетенції можуть бути предметом вдосконалення та цілеспрямованого розвитку, а їх розвиток відбувається шляхом переосмислення ситуацій лідерської взаємодії у процесі набування студентами позитивного досвіду у спілкуванні. Дослідник вважає, що під час формування лідерських компетенцій у студентів особливої теоретичної уваги та практичної значущості набувають удосконалення та розвиток таких ключових характеристик, як комунікативні здібності, орієнтація на результат, емоційний інтелект та аналітичне мислення, що стають провідними у змісті лідерських компетенцій [10].

Оскільки за сучасних умов та вимог, що ставляться до підготовки спеціалістів, неможливо заперечувати важливість стимулювання та розвитку 
лідерських компетенцій у студентів та необхідно звернути увагу на культуру освіти загалом, перебудову системи виховання студентів для того, щоб мати змогу вчасно виявити майбутніх лідерів, надати їм підтримку та просувати їх лідерський потенціал. Ученими виявлено, що ефективне лідерство у студентському віці забезпечують наступні риси, такі як здатність до самоствердження, самопізнання, самовизначення, яскраво виражена самостійність, а також ентузіазм, громадська активність та прагнення до колективності. В цілому усі складові, які гарантують ефективне лідерство та розвивають лідерські компетенції у студентів можна розділити на три основні групи:

- мотиваційні складові, до складу яких входять потреба в досягненні високих результатів, упевненість у собі, прагнення до самореалізації і самоствердження;

- емоційно-вольові, які включають емоційно позитивне самопочуття, урівноваженість та наявність вольових якостей;

- ділові складові, що містять готовність брати на себе відповідальність, уміння приймати правильне рішення в непередбачених ситуаціях, а також уміння та навички організаторської роботи [12, с. 79].

Кононова Т.О. виокремлює чотири головні компоненти у процесі формування лідерської компетенції студентів, а саме:

•когнітивний або пізнавальний;

•мотиваційний;

•операційний;

•рефлексивний.

Когнітивний або пізнавальний компонент припускає формування у студентів економічних, соціально-політичних та психолого-педагогічних знань, які є необхідними для виявлення лідерських компетенцій. До складу цього компонента входить єдність теоретичних, методологічних та технологічних знань, що поєднують професійні знання та вміння ними користуватися при розв'язанні професійних завдань [5, с. 166].

Мотиваційний компонент передбачає формування стійких мотивів діяльності згідно з гуманістичними цінностями, наприклад прагнення діяти, прийняття ролі лідера як власного психологічного стану, бажання брати на себе функції лідера в різноманітних складних ситуаціях тощо [5, с. 167].

Операційний компонент передбачає створення ситуацій, у яких студенти матимуть можливість проявити свої лідерські якості, а також здатність до практичної дії, ризику та швидкого знаходження рішення. Тобто, цей компонент становить собою комплекс умінь використовувати на практиці лідерські якості у різних професійних ситуаціях та здійснювати самоосвітню діяльність у майбутньому. Крім того, він передбачає активну та якісну взаємодію між студентом та викладачем, під час якої викладач визначає мету, завдання й створює умови для активної пізнавальної діяльності студентів, а також контролює, направляє та мотивує студентів. 
Журнал«Герспективитаінновації наукиљ

(Серія«Гедагогіка», Серія«ПЕихологія», Серія«Медицина»

№5(5) 2021

Рефлексивний компонент виявляється в осмисленні та усвідомленні студентами власних вчинків, дій, способів лідерства та прийомів, здатності проводити самооцінку та самоаналіз своїх лідерських дій, а також в умінні поєднувати одержані результати з поставленими цілями [5, с. 170].

Для того, щоб забезпечити високу ефективність процесу формування лідерської компетенції студентів слід особливу увагу звернути на ряд важливих напрямів роботи. По-перше, слід розвивати органи студентського самоврядування, які створені на базі навчального закладу, для прикладу, профспілки, громадські організації та молодіжні об'єднання, на базі яких студентська молодь матиме змогу виокремлювати, аналізувати та розв'язувати різні молодіжні проблеми, створювати та втілювати в житті нові проєкти, виражати особисту думку та реалізовувати свої лідерські амбіції, а також поступово формувати власне професійне портфоліо, що міститиме здобуті досягнення за час навчання.

По-друге, варто розширювати спектр можливостей самореалізації студентів через їх участь у позанавчальних об'єднаннях за інтересами, наприклад забезпечувати діяльність різноманітних інтелектуальних, творчих, волонтерських, спортивних гуртків, об'єднань, секцій та клубів. У таких об'єднаннях студенти зможуть розвивати себе, розкрити свій лідерський потенціал та примножувати його.

По-третє, необхідно стимулювати проєктну діяльність студентів шляхом їх участі у конкурсах грантів для обдарованої молоді, навчальних закладів та громадських організацій для того, щоб розвивати в них амбітність, цілеспрямованість, прагнення до перемоги, націленість на позитивний результат та реалізацію власних соціально важливих ініціатив [13, с. 55].

Саме ці особливості створюють передумови для формування у студентів творчого, аналітичного мислення, мотивують їх до самореалізації, самовдосконалення та розвитку особистісного потенціалу, а також сприяють формуванню у них вміння відстоювати та аргументувати свою думку та мати власну позицію, що в майбутньому може стати підгрунтям для розвитку їх лідерських якостей та лідерської компетенції.

Дослідники виокремлюють максимально сприятливі види діяльності для розвитку лідерських компетенцій, до цих видів відносяться:

•навчальна діяльність, яка може бути індивідуальною, груповою та колективною;

•конкурсна діяльність, що охоплює участь у різноманітних змаганнях та конкурсах;

•дослідницько-пошукова діяльність, яка включає участь у проєктах, конференціях, тренінгах та програмах;

-проєктивна діяльність, що передбачає розробку та захист індивідуальних і колективних справ; 
•громадська діяльність, яка охоплює участь у роботі органів самоврядування, в молодіжних організаціях та асоціаціях, а також волонтерський рух;

•представницька діяльність, яка передбачає уміння презентувати себе, молодіжну організацію чи групу однолітків [8, с. 87].

Для прикладу розглянемо навчальну діяльність як підгрунтя для формування лідерських компетенцій у студентів. Формування лідерських компетенцій у навчальній діяльності відбувається під час упровадження в навчальний процес нестандартних, творчих, інноваційних методів навчання, які мають ряд особливостей, зокрема, взаємовідносини між викладачем та студентами мають бути побудовані на основі співробітництва; проблемний, діалогічний стиль викладання; застосування переважно групових форм організації освітнього процесу; демократичний стиль взаємовідносин; забезпечення психологічного комфорту та створення ситуацій успіху у навчанні; використання дослідницьких i проблемно-пошукових методів навчання; реалізація принципу вибірковості у навчанні.

Вагоме місце у процесі формування лідерських компетенцій у студентів посідає й виховна робота з ними. У процесі організації виховної роботи зі студентами, варто мати на увазі, що перед сучасними фахівцями стоїть завдання організації своєї професійної діяльності в непростих умовах, які постійно змінюються та ускладнюються, а тому від них вимагається постійний доказ життєздатності своїх розумових та професійних знань. А тому, студентам необхідно допомогти повною мірою використовувати їх потенційні можливості, набути різноманітні форми лідерського досвіду, які становитимуть основу їх життєдіяльності в майбутньому. Отриманий лідерський досвід під час навчання сприятиме виживанню та пристосуванню до мінливих соціальних та економічних умов у майбутньому [2].

Однак, у процесі організації виховної роботи потрібно враховувати ряд особливостей, які ускладнюють формування лідерських компетенцій, а саме невміння працювати в команді; домінування особистих взаємин над професійними; надмірний контроль i нечіткий розподіл обов'язків. Ці проблеми заслуговують першочергової уваги при організації та проєктуванні процесу формування лідерських компетенцій в кожному конкретному навчальному закладі [10].

Наголосимо, що значну роль у процесі формування у студентів лідерської компетенції належить викладачу, адже він $є$ головним організатором освітнього процесу та йому необхідно надихати студентів, залучати їх до творчої та наукової діяльності, показати їм цікавий та важливий світ наукових досліджень, що є проявами лідерства, яке насамперед пов'язане з умінням гідно прийти зміни та швидко пристосовуватися до нових та у більшості випадків складних ситуацій [3]. Зокрема, дослідниця I. Ковальова висловила думку про те, що основним завданням викладача як керівника та як лідера полягає у розв’ язанні проблем, що постають перед колективом, 3 найбільшим 
соціально-психологічним та економічним ефектом [6, с. 21].

3 огляду на все вищесказане, ми переконані, що основним інструментом для формування лідерської компетенції у студентів $\epsilon$ створення педагогічних умов, які б поєднували традиційні підходи до навчання та виховання 3 новітніми педагогічними технологіями. Це обумовлюється тим, що педагогічні умови спрямовані не тільки на введення певних методів та форм роботи, а й на створення особливо організованого середовища, в якому студенти мали б можливість особистісного зростання та розкриття їх лідерського потенціалу.

Ми підтримуємо точку зору більшості дослідників та вважаємо, що для формування у студентів лідерської компетенції дуже важливо забезпечити необхідні умови, за яких стане можливим розкриття їх лідерських задатків та якостей. До таких умов відносяться:

•залучення студентів до такого виду діяльності, що зробить можливим зайняття лідерської позиції та забезпечить виконання лідерських функцій й демонстрацію лідерської поведінки;

•спільна творчість студентів та викладачів, а також створення сприятливої атмосфери та позитивного психологічного мікроклімату в студентському колективі;

-діагностика та корекція особистісного розвитку студента в контексті професійних вимог до обраного виду діяльності;

•надання студентам можливості займати лідерську позицію у спільній діяльності;

-взаємодія, що зорієнтована на особистість у системі «викладачстудент» і «викладач-студентська група» та заснована на принципах поваги, довіри та партнерства;

•створення сприятливої атмосфери та позитивного психологічного мікроклімату в студентському колективі;

•формування стійких установок на професійне самовиховання [8, с. 81].

Ми рекомендуємо процес формування лідерських компетенцій у студентів організовувати у декілька послідовних етапів. Перший етап полягає у послідовному орієнтуванні особистості на ціннісне осмислення лідерських компетенцій. Під час реалізації цього етапу особлива увага має звертатися на засвоєння студентами ряду важливих питань, а саме питань про особистість, іiі мотивацію, активність, структуру, спрямованість, характер та здатності [2]. Так, поступово у студентів 3'являються можливості та потреби, що лежать в основі лідерського потенціалу. Окрім того, з ними необхідно обговорювати питання ставлення до самого себе й важливості формування лідерських якостей, а також ставлення до життя. Цей етап може бути реалізований під час спеціальних занять у групах, що поєднуються 3 індивідуальними консультаціями та участю студентів у дискусіях, проблемних діалогах, бесідах, які спрямовані на стимулювання та мотивацію студентів та підвищення їх поінформованості. 
На другому етапі відбувається залучення студентів до лідерських дій у спеціально організованих пізнавальних та професійних ситуаціях. Цей етап передбачає організацію спеціальних ситуацій в тренінгах та ділових іграх, які сприяють розвитку лідерського потенціалу особистості. Важливо, щоб такий вплив на студентів здійснювався протягом всього навчання послідовно, адже у процесі їх залучення до таких активних дій відбуваються значущі зміни у соціальнокомунікативних i організаторських якостях їх особистостей [5, с. 177]. Таким чином, залучаючи студентів до лідерських дій у спеціально організованих ситуаціях, ми закладаємо основу їх поведінки надалі, оскільки розглядаються можливі варіанти та виробляється певний зразок поведінки. Дуже важливо, створюючи спеціальні ситуації, домагатися активної участі в них студентів, щоб всі відчули свої потенційні лідерські можливості, спробували їх реалізувати та набули певний лідерський досвід.

Третій етап полягає у збагаченні лідерського досвіду студентів у позанавчальній діяльності. Цей підхід є своєрідною стратегією, що дає змогу активізувати лідерські можливості у процесі становлення особистості і як лідера, і як професіонала. Цей етап реалізується у формі мінікурсів, які допомагають студентам правильно побудувати свій виступ перед аудиторією, обрати оптимальне рішення 3 усіх можливих, спрогнозувати можливий результат діяльності за умов ситуаційної невизначеності, опанувати навички самоорганізації в пізнавальні та професійній діяльності тощо [3, с. 131].

Висновки. Отже, проведене дослідження свідчить, що в сучасних умовах реформування освіти України особливо важливого значення набуває проблема формування лідерської компетенції у студентів як одного із найважливіших аспектів становлення майбутнього спеціаліста, його професійної діяльності та професійного іміджу.

Встановлено, що лідерська компетенція виявляється у здатності студента помічати зміни, передбачати тенденції, швидко реагувати на зміни, узгоджувати власні потреби й цінності з потребами та цінностями інших людей 3 метою злагодженої й ефективної діяльності та формування команди, а також створювати всі необхідні умови для досягнення мети та чітко й наполегливо рухатися до їі досягнення.

Окрім того, лідерська компетенція охоплює ряд важливих здібностей лідера, серед яких аналітичні, технічні, діагностичні здібності, гнучкість, ініціативність, саморегуляцію, відповідальність за власні дії таза дії команди, а також вміння організовувати та координувати спільну командну роботу й спілкуватись $з$ людьми.

Для того, щоб формувати лідерські компетенції у студентів, необхідно у навчально-виховному процесі створювати сприятливі педагогічні умови та забезпечувати злагоджену роботу колективу викладачів. А також залучати студентів до того виду діяльності, який зробить можливим зайняття лідерської позиції та забезпечить виконання лідерських функцій й демонстрацію лідерської поведінки, створювати сприятливу та доброзичливу атмосферу як у 
рамках студентської групи, так і під час взаємодії студентів із викладачами й організовувати взаємодію, що зорієнтована на особистість у системі «викладач-студент» і «викладач-студентська група» та заснована на принципах поваги, довіри та партнерства.

Доведено, що у процесі формування лідерських компетенцій у студентів потрібно опікуватися створенням спеціальних ситуацій для надання їм можливості реалізувати свій лідерський потенціал та розвивати свої здібності, адже ці здібності можна й потрібно розвивати та необхідно навчатися лідерству. Це можна реалізувати в навчальній діяльності в процесі вирішення навчальних завдань, у науковій роботі шляхом участі у різноманітних наукових студентських товариствах, виступах на науково-практичних конференціях, участі у наукових конкурсах, а також у позанавчальній діяльності через участь у громадській діяльності, наприклад, участь у роботі органів студентського самоврядування, волонтерський рух, участь у творчих групах та молодіжних організаціях тощо. Адже, студентські роки - це період, коли кожен студент може не лише виявити свої лідерські здібності, а й розвинути їх та зробити міцним підгрунтям для своєї майбутньої професійної діяльності.

До перспектив подальших наукових розвідок порушеної проблеми слід віднести питання комплексного аналізу процесу формування лідерських компетенцій у студентів.

\section{Jimepamypa:}

1.Вежевич Т.Е. Педагогические условия развития лидерских качеств учащихся: дисс. канд. пед. наук: 13.00.01. Улан-Удэ, 2017. 198 с.

2. Волосюк Т.В. Проблема формування лідерської компетенції студентів вищої школи. URL: https://essuir.sumdu.edu.ua/bitstream-download/123456789/38027/1/Volosyuk.pdf (дата звернення: 20.09.2021).

3. Волосюк Т.В. Роль лідерської компетенції у формуванні професійного іміджу студентів в умовах ВНЗ. Вісник Глухівського національного педагогічного університету імені Олександра Довженка. Сер.: Педагогічні науки. 2015. № 27. С. 126-131.

4. Гармаш С.А. Лідерські якості особистості керівника як запорука успіху. Управління інноваційними проєктами та об'єктами інтелектуальної власності. 2019. С. 37-44.

5. Кононова Т.О. Методика формування лідерських компетенцій у процесі професійного становлення іноземного студента ц вищому навчальному закладі інженерно-педагогічного профілю. Збірник наукових праць Національної академії державної прикордонної служби України. Серія: Педагогічні та психологічні науки. 2017. № 4 (73). С. 166-175.

6. Мухіна К. А., Денисенко Я.А., Штученко І.С. Психологічні засади формування лідерських якостей студентів. Психологічний інструментарій розвитку лідерського потенціалу сучасної молоді: теорія і практика: матеріали науково - практичної конференції 17 жовтня 2019 р.: за заг. ред. Романовського О.Г. Харків: НТУ «ХПІ». 2019. С. 21-22.

7. Парыгин Б.Д. Основы социально-психологической теории. URL: http://mhpjournal.ru/upload/2010_v5_n2/2010_v5_n2_12.pdf (дата звернення: 20.09.2021).

8. Романовский А. Г. Педагогика лидерства : монография / за ред. А. Г. Романовский, В. Е. Михайличенко, Л. Н. Грень. Нац. техн. ун-т «Харьков. политехн. ин-т». Харьков: НТУ «ХПИ», 2018. $496 \mathrm{c.}$

9. Сергеєва Л. М., Кондратьєва В.П., Хромей М.Я. Лідерство: посібник. ІваноФранківськ, 2015. 296 с. 
10. Савицька Т.В., Іотова І.Н., Маджар Н.М. Особливості формування особистості лідера в студентському колективі. URL: http://elib.umsa.edu.ua/bitstream/umsa/13658/1/ Savicka_Osoblivosti_formuvannya.pdf (дата звернення: 20.09.2021).

11. Хмизова О. В. Формування лідерської позиції у майбутніх учителів початкових класів як складової їх професійної компетентності. Збірник наукових праць «Педагогічні науки». 2017. № 44. С. 316-320.

12. Чорний А.В. Сучасні теорії лідерства: Загальний огляд та структурна модель. Наукові записки Національного університету «Острозька академія». Серія «Економіка»: Науковий журнал. Острог: вид-во НаУОА, 2018. № 9(37). С.78-84.

13. Яценко О. М., Горбунов М. П. Формування лідерських якостей майбутніх менеджерів у процесі професійної підготовки: монографія / О. М. Яценко, М. П. Горбунов. Харків, 2018. 250 с.

\section{References:}

1.Vezhevych, T.E. (2017). Pedahohycheskye uslovyia razvytyia lyderskykh kachestv uchashchykhsia [Pedagogical conditions for the development of leadership qualities of students]. Extended abstract of candidate's thesis. Ulan-Udэ [in Russian].

2. Volosiuk, T.V. (2014). Problema formuvannia liderskoi kompetentsii studentiv vyshchoi shkoly [The problem of forming the leadership competence of high school students]. Retrieved from: https://essuir.sumdu.edu.ua/bitstream-download/123456789/38027/1/Volosyuk.pdf [in Ukrainian].

3. Volosiuk, T.V. (2015). Rol liderskoi kompetentsii u formuvanni profesiinoho imidzhu studentiv $\mathrm{v}$ umovakh VNZ [The role of leadership competence in the formation of professional image of students in the university]. Visnyk Hlukhivskoho natsionalnoho pedahohichnoho universytetu imeni Oleksandra Dovzhenka - Bulletin of the Glukhiv National Pedagogical University named after Oleksandr Dovzhenko, 27, 126-131 [in Ukrainian].

4. Harmash, S.A. (2019). Liderski yakosti osobystosti kerivnyka yak zaporuka uspikhu [Leadership qualities of the leader as a guarantee of success]. Upravlinnia innovatsiinymy proiektamy ta obiektamy intelektualnoi vlasnosti - Management of innovative projects and intellectual property, 37-44 [in Ukrainian].

5. Kononova, T.O. (2017). Metodyka formuvannia liderskykh kompetentsii u protsesi profesiinoho stanovlennia inozemnoho studenta ts vyshchomu navchalnomu zakladi inzhenernopedahohichnoho profiliu [Methods of formation of leadership competencies in the process of professional development of a foreign student in a higher educational institution of engineering and pedagogical profile]. Zbirnyk naukovykh prats Natsionalnoi akademii derzhavnoi prykordonnoi sluzhby Ukrainy - Collection of scientific works of the National Academy of State Border Guard Service of Ukraine, 4 (73), 166-175. [in Ukrainian].

6. Mukhina, K. A., Denysenko Ya.A., Shtuchenko I.Ie. (2019). Psykholohichni zasady formuvannia liderskykh yakostei studentiv [Psychological principles of forming leadership qualities of students]. Proceedings from: materialy naukovo - praktychnoi konferentsii «Psykholohichnyi instrumentarii rozvytku liderskoho potentsialu suchasnoi molodi: teoriia $i$ praktyka» - materials of the scientific-practical conference «Psychological tools for the development of leadership potential of modern youth: theory and practice». (pp. 21-22). Kharkiv: $\mathrm{NTU}$ «KhPI» [in Ukrainian].

7. Paryhyn, B.D. (2010). Osnovy sotsyalno-psykholohycheskoi teoryy [Foundations of sociopsychological theory. Retrieved from: http://mhp-journal.ru/upload/2010_v5_n2/2010_v5_n2_12.pdf [in Russian].

8. Romanovskyi, A. H. (2018). Pedahohyka lyderstva [Leadership Pedagogy]. Monograph. Kharkov: NTU «KhPY» [in Russian].

9. Serheieva, L. M., Kondratieva V.P., Khromei M.Ia. (2015). Liderstvo [Leadership]. IvanoFrankivsk [in Ukrainian]. 
10. Savytska, T.V., Iotova I.N., Madzhar N.M. (2020). Osoblyvosti formuvannia osobystosti lidera $v$ studentskomu kolektyvi [Features of the formation of the leader's personality in the student body]. Retrived from: http://elib.umsa.edu.ua/bitstream/umsa/13658/1/Savicka_Osoblivosti_ formuvannya.pdf [in Ukrainian].

11. Khmyzova, O. V. (2017). Formuvannia liderskoi pozytsii u maibutnikh uchyteliv pochatkovykh klasiv yak skladovoi yikh profesiinoi kompetentnosti [Forming a leadership position in future primary school teachers as part of their professional competence]. Zbirnyk naukovykh prats «Pedahohichni nauky» - Collection of scientific works "Pedagogical sciences", 44, 316-320. [in Ukrainian].

12. Chornyi, A.V. (2018). Suchasni teorii liderstva: Zahalnyi ohliad ta strukturna model [Modern theories of leadership: An overview and structural model]. Naukovi zapysky Natsionalnoho universytetu «Ostrozka akademiia» - Scientific notes of the National University "Ostroh Academy”, 9 (37), 78-84 [in Ukrainian].

13. Yatsenko, O. M., Horbunov M. P. (2018). Formuvannia liderskykh yakostei maibutnikh menedzheriv $\mathrm{u}$ protsesi profesiinoi pidhotovky [Formation of leadership qualities of future managers in the process of professional training]. Monograph. Kharkiv [in Ukrainian]. 